\title{
Preparation and characterization of silver nanoparticles and their use for improving the quality of apricot fruits
}

\author{
M. Shahat ${ }^{1}$, M. I. Ibrahim ${ }^{1,}{ }^{*}$, A. S. Osheba ${ }^{2}$ and I. M. Taha ${ }^{1}$ \\ ${ }^{1}$ Food Science and Technology Department, Faculty of Agriculture, Al-Azhar University, Nasr city, Cairo, Egypt \\ ${ }_{2}^{2}$ Meat and Fish Technology Research Department, Food Technology Research Institute, Agricultural Research \\ Center, Giza, Egypt
}

* Corresponding author email: Mohammedibrahim700.el@azhar.edu.eg (M. I. Ibrahim)

\begin{abstract}
Nanotechnology is one of the most recent innovations. Silver nanoparticles (AgNPs) have recently gained increasing interests due to their antimicrobial activities in food applications. This study aims to synthesize and characterize some features of AgNPs as well as to use such particles in improving the quality of apricot fruits. Silver nanoparticles were synthesized by starch as an economic and efficient method. The size and shape of the synthesized AgNPs were observed by transmission electron microscopy (TEM) techniques. The antimicrobial and antioxidant activities of AgNPs were evaluated. Nanoparticle solutions of Ag were applied as active coatings on apricot fruits. Samples were divided into two groups; the first group was kept at ambient temperature $\left(25 \pm 3^{\circ} \mathrm{C}\right)$ and the other group was kept at cold temperature $\left(6 \pm 2^{\circ} \mathrm{C}\right)$. Results of TEM revealed that AgNPs were nearly spherical shapes with a size range of $9.52-26.4 \mathrm{~nm}$. The inhibition zones ranged from 20.8 to $24.7 \mathrm{~mm}$ for investigated bacterial strains, while were 17 and $20 \mathrm{~mm}$ for fungi strains. Also, the results revealed an efficient antioxidant activity of AgNPs. During storage at the different temperatures, the samples coated with AgNPs had lower values for weight losses, decay, total soluble solids and malondialdehyde concentration, while such samples had higher levels of total acidity and total carotenoids compared to control, and consequently lead to preserving their quality properties and extending of the shelf life. Based on comprehensive comparison and evaluation, apricots coated by AgNPs could be kept in good quality for 8 days at $25 \pm 3^{\circ} \mathrm{C}$ or for 24 days at $6 \pm 2^{\circ} \mathrm{C}$.
\end{abstract}

Keywords: Silver nanoparticles, electron microscopy, antimicrobial activity, antioxidant activity, shelf-life, apricot.

\section{INTRODUCTION}

Apricot (Prunus armeniaca L.) is a palatable stone fruit, rich in nutritional and health promoting compounds (Muzzaffar et al., 2018). Canino apricots are one of the most important cultivars grown in newly reclaimed lands in Egypt (Abd-Elwahab, 2015). Egypt is considered the $12^{\text {th }}$ largest producer of apricots worldwide. In 2018 total apricot production in Egypt was 96226 tons according to FAOSTAT (2018). A pricots a fragile fruit with a short shelf life, as it is prone to rapid ripening and rotting after harvest (Mohamed et al., 2019). Microbiological spoilage leads to postharvest losses about 15 to $50 \%$ of fruits and vegetables produced worldwide (Swaminathan, 2016). In developing countries, the percentages of product losses are quite high due to a lack of appropriate technologies for postharvest storage of fruits and vegetables (Kumar et al., 2019). During storage, apricots undergo the softening and rotting, which largely result in the loss of quality, microbial decay, and mechanical injury. To date, low-temperature storage is the method most widely used to extend the shelf life and maintain the postharvest quality of apricots (Wang et al., 2015). However, long-term storage at low temperatures could cause some physiological disorder in apricot fruits such as chilling injury (Cui et al., 2019).

Films and coatings can be used to help the preservation of the fruit. The coating may be defined as the thin layer of material on food surfaces which acts as a hurdle between food and the surrounding environment (Majid et al., 2016). Recently, functional coatings have been developed, which not only modify the internal environment of fruits but also add value to the product. In fresh fruits, these coatings also retain the phytochemicals and physicochemical properties for a longer period. Coatings also save preservation costs in comparison to other methods. Therefore, it can be concluded that coating is one of the best methods for the preservation of fresh fruits (Sharma et al., 2019).

Now, nanotechnology has been used in the improvement of coating technology for the preservation of fruits using diverse nanosystems such as nanocomposites, nanoparticles and nano-emulsions (Zambrano-Zaragoza et al., 2018). Coatings are employed as matrixes for incorporating antimicrobial nanoparticles (Xing et al., 2019). Among nanoparticles, silver nanoparticles (AgNPs) are the most studied as they have shown to be effective against various microorganisms and are safe for humans (Aadil 
et al., 2018 and Onitsuka et al., 2019). As silver has long been known to exhibit strong toxicity to a wide range of microorganisms, with low systemic toxicity toward human it is a great advantage to utilize silver-based compounds for antimicrobial applications against foodborne pathogens as well as antioxidants to maintain the food quality. The unique physicochemical characteristics of AgNPs have attracted attention in various fields of science and technology. These advantages are useful for improving technologies used in agricultural (biopesticides, food preservation) and biomedical (wound dressings, catheters, dental materials, bone cement and drugs) areas (Gordienko et al., 2019). Over the past decades, AgNPs have been defined as food additives and/or food contact materials in consumer products, mostly because of their antimicrobial properties (Monge and Moreno-Arribas, 2016). Thus, AgNPs have achieved a renewed, increasing and interest due to the search for new antimicrobial alternatives that could replace or complement the action of food chemical preservatives (Gil-Sanchez et al., 2019).

In this context, novel and recent applications of AgNPs have been introduced to the field of the food industry. In particular, AgNPs has been proposed as a new alternative to replace or complement the antiseptic properties of $\mathrm{SO}_{2}$ owing to the potential risks of sulfites to human health (Garcia-Ruiz et al., 2015). The practical application of edible coating with incorporated silver nanoparticles has been already tested on several foods such as fruit and vegetables, meat, and cheese. Nevertheless, so far, the studies have been conducted on a laboratory scale (Kraśniewska et al., 2020). The beneficial effects of AgNPs on the shelf life and quality of food have been investigated in some previous studies. Bakhy et al. (2018) studied the effect of the edible coating containing AgNPs on the quality attributes of apples, red grapes, tomatoes and sweet green pepper. Their results indicated that the application of nano-coating led to reduced weight losses percentage and extended shelf life. Also, Chandirika et al. (2018) applied AgNPs as a coating in the tomato stored at room temperature. Results conclude that the coated tomato showed a good shelf life period from 16 to 21 days when compared with control (non-coating). In addition, Wasiu Oluwatofarati et al. (2018) studied the effect of coating with a suspension containing AgNPs on meat qualities and showed that the qualities of meat were positively affected by AgNPs treatment.
In recent studies, Ortiz-Duarte et al. (2019) observed the effect of chitosan coating containing AgNPs on the quality of the freshcut melon. They found that Ag-chitosan nanocomposites extend the shelf-life of freshcut melon up to 13 days. Also, this coating had a greater inhibitory effect on the counts of psychrophiles, enterobacteria, yeasts and molds compared to the uncoated sample. Also, Kowsalya et al. (2019) found that the use of coating AgNPs and polyvinyl alcohol on surface of lemon and strawberries led to extend the shelf life of treated fruits up to ten days (the coated fruits were acceptable in terms of color, appearance, texture and weight) compared to the uncoated fruits that were qualified as unacceptable after the third storage day. In a more recent study, Saravanakumar et al. (2020) found that the application of nano-coating containing AgNPs and polyvinylpyrrolidone extended the shelf life of the red and yellow fresh cut bell pepper for 12 days at $4^{\circ} \mathrm{C}$ without causing any harm to cellular or physicochemical properties of fresh-cut bell pepper.

In general, the results of previous researchers suggested the potential application of AgNPs as a preservative agent in the food industry to augment the shelf life of fresh food for the future. Therefore, this study is one of these tries seeking to: synthesize and characterize some features of AgNPs as well as their use for improving the quality of apricot fruits. Also, evaluation of physical and chemical changes for treated fruits during storage at different temperatures to determine shelf life.

\section{MATERIALS AND METHODS}

\section{Raw material:}

Fresh apricot fruits (Prunus armeniaca L.) "canino" were obtained from a local market at Cairo Governorate, Egypt. Where it harvested in mid-Jun, 2019. Immediately after they arrived at the store, the fruits were transported to the laboratory and then they were graded for ripe stage (greenish-yellow skin color and firm flesh).

\section{Chemicals:}

Silver nitrate (assay $>99.9 \%$, Merck) and maize starch was purchased from the Egyptian Company for Starch and Glucose manufacture, Cairo, Egypt. The other chemicals used for this study were purchased from El-Nasr Pharmaceutical Chemicals Company, Cairo.

\section{Microorganism strains:}


Four bacterial strains representing gramnegative (Escherichia coli and Salmonella typhimurium), gram positive bacteria (Staphylococcus aureus and Bacillus subtilis), in addition to two fungi strains (Aspergillus niger, and Aspergillus flavus) were obtained from Chemistry of Natural and Microbial product Department, National Research Center, Cairo, Egypt. These microorganisms were checked for their purity and identity, then finally recultivated to obtain active cultures.

\section{Methods:}

\section{Synthesize of silver nanoparticles:}

Silver nanoparticles were prepared according to the method described by El-Rafie et al. (2014). Starch was dissolved in alkali solution $(1 \mathrm{~g}$ starch in $80 \mathrm{ml}$ of distilled water containing $2 \mathrm{~g}$ sodium hydroxide) by using high-speed homogenizer. After complete dissolution the temperature of the reaction medium was raised to the desired degree $\left(60^{\circ} \mathrm{C}\right)$. In this moment, $20 \mathrm{ml}$ silver nitrate solution $(10 \mathrm{mM})$ was added dropwise. The reaction medium was kept under continuous stirring for 60 minutes. After complete reaction, the solution was allowed to cool down slowly to $25^{\circ} \mathrm{C}$. Then the St-AgNPs were precipitated using absolute ethyl alcohol under high-speed homogenizer. The powder precipitate was collected by centrifugation at $4,500 \mathrm{rpm}$ for 15 min, washed twice with 80/20 ethanol/water to remove the unreacted materials and impurities, and then finally washed with absolute ethanol. The collected powder was dried and identified as St-AgNPs using state-of-the-art facilities.

\section{Characterization studies of the synthesized silver nanoparticles:}

\section{Visual inspection:}

The reduction of silver ions was roughly monitored by visual inspection of the solution as the method described by Anjum et al. (2019).

\section{Transmission electron microscopic measurements:}

The morphological features of AgNPs were examined by High-Resolution Transmission Electron Microscopy (TEM), which provides accurate information about the size and shape of the formed nanoparticles. TEM characterization is performed using (JEOL, JEM-1230, Japan) instrument with an acceleration voltage of $120 \mathrm{kV}$ as the method described by Hebeish et al. (2016).

Antimicrobial activity for the synthesized silver nanoparticles:
The antimicrobial activity of the AgNPs (at concentrate $100 \mu \mathrm{g} / \mathrm{mL}$ ) was tested against both gram-negative and gram-positive bacteria, as well as fungi strains by using the agar well diffusion method. The antibacterial activity of AgNPs was evaluated according to the method of Mokhena and Luyt (2017). While, the antifungal activity was evaluated as method described by Balouiri et al. (2016). The inhibition zones were calculated by measuring the diameter of the inhibition zone around the well (in $\mathrm{mm}$ ) including the well diameter.

\section{Antioxidant activity for the synthesized silver nanoparticles:}

The antioxidant activity of AgNPs (at different concentrations of 25, 50, 75 and $100 \mu \mathrm{g} / \mathrm{ml}$ ) was evaluated by 1,1-diphenyl-2picrylhydrazyl (DPPH) radical scavenging method reported by Sundararajan et al. (2016). Compared to ascorbic acid as a standard antioxidant at the same concentrations.

Application of silver nanoparticles as active coatings on apricot fruits:

\section{Preparation of coating solution:}

The coating solutions were prepared by adding AgNPs (at concentration 250 or 500 $\mathrm{ppm})$ and glycerol as a plasticizer $(1.5: 100 \mathrm{v} / \mathrm{v})$. The solution was stirred over a magnetic stirrer for $15 \mathrm{~min}$ at ambient temperature before use.

\section{Preparation of coated apricot fruits:}

The apricot fruits were washed with potable water and left to aerobic dry then were immersed in the coating solutions containing AgNPs while the control sample (uncoated) was then immersed in distilled water and left to dry. Then, the samples were divided into two groups: the first kept at ambient temperature $\left(25 \pm 3^{\circ} \mathrm{C}\right)$ and the other group kept at cold temperature $\left(6 \pm 2^{\circ} \mathrm{C}\right)$. The treated apricot samples were periodically analyzed every 2 days for the former or 4 days for the later during storage.

Determination of physical and chemical quality criteria for coated fruits:

\section{Weight loss:}

The weight loss percentage was calculated as reported by Qin et al. (2015) by the following equation:

Fruit weight loss $(\%)=[$ (initial weight weight at sampling date/initial weight)] x 100 .

\section{Inspection of visual decay:}

The decay rate was used to assess the decrease in quality by the percentage of rot 
fruit. The decay (\%) was calculated according to the method described by Li et al. (2019).

Decay $(\%)=($ Number of affected fruits at specified storage period/initial number of stored fruit) $\times 100$.

\section{Total soluble solids:}

Total soluble solids (TSS) content (\%) was determined using a hand refractometer according to AOAC. (2016).

\section{Total titratable acidity:}

Total titratable acidity (\%) was assayed based on the method described by Hajji et al. (2018). It calculated as grams of malic acid per $100 \mathrm{~g}$ of fresh weight.

\section{Malondialdehyde concentration:}

The malondialdehyde (MDA) concentration was analyzed according to the method described by Liu et al. (2018).

\section{Total carotenoids content:}

Total carotenoids in apricot fruits were extracted according to the method described by Akin et al. (2008). Total carotenoids content was measured by a spectrophotometer at wavelength of $450 \mathrm{~nm}$.

\section{Determination of total silver concentration:}

Apricot samples were digested in an acid solution using Anton-Paar microwave digestion system (Multi wave PRO). Table (1) shows the operating conditions for the determination of silver ions using the Agilent 5100 Synchronous Vertical Dual View inductively coupled plasma-optical emission spectrometry (ICP-OES). All samples were digested to have an acceptable matrix for measuring silver ions and to provide acceptable and consistent recovery compatible with the analytical method of APHA et al. (2017). The concentration of silver was determined by using ICP-OES in National Research Center, Giza, Egypt.

\section{Shelf-life study:}

The shelf life of apricots was calculated by counting the days required for them when they remained acceptable for marketing according to Mondal (2000).

\section{Statistical analysis:}

The experiment was conducted in a completely randomized design with three replications. Statistical analysis was performed using the Cohort software (Costat, 1986). Oneway ANOVA at the level of significance $p<0.05$ using the Duncan test was performed for comparison of means.

\section{RESULTS AND DISCUSSION:}

\section{Synthesize of silver nanoparticles:}

Silver nanoparticles were prepared by alkali treated method. In this method, the starch used as both reducing and protecting agent, however it could be quite simply suggested as follows: alkali treatment is supposed to increase the solubility of starch by rupturing the granules and then degrading starch macro molecules to give smaller fragments with higher reducing power. Also, it acts in increasing the affinity of the free hydroxyl groups of sugars by removing the protons which in turns assist the formation of silver nanoparticles.

Generally, for synthesis of AgNPs, the accepted mechanism suggests a two-step process: In the first step, a portion of metal ions in a solution is reduced by the reducing agent (starch fragments). In the second step, the atoms produced act as nucleation centers and catalyze the reduction of the remaining metal ions present in the bulk solution. Subsequently, the atoms coalesce leading to the formation of metal clusters.

\section{Characterization of produced silver nanoparticles:}

\section{Visual inspection of nanoparticles:}

A short time after the addition of $\mathrm{AgNo}_{3}$ solution into starch solution during the synthesis of AgNPs, the reaction medium acquired a clear yellow color then changed to brown and finally to dark brown color during stirring the solution. Along with mirror-like illumination on the walls of Erlenmeyer flask clearly indicated the formation of AgNPs in the reaction mixture as shown in Fig. (1).

\section{Particle size and morphological properties of nanoparticles:}

Transmission electron microscope imaging showed the morphological properties and surface appearance of AgNPs which have a nearly spherical shape and smooth surface. As illustrated in Fig. (2), it was observed that the prepared nanoparticles were an average particle size of 9.52 - $26.4 \mathrm{~nm}$. Furthermore, these nanoparticles are well dispersed with no sign of aggregation.

\section{Antimicrobial activity of silver nanoparticles:}

The effect of silver nanoparticles on the growth of studied microorganisms was presented in Fig. (3). AgNPs showed various 
degrees of inhibition against the tested microorganisms.

For the antibacterial investigation, the inhibition zones of AgNPs were ranged from 20.8 to $24.7 \mathrm{~mm}$. The highest inhibition zone was obtained for E. coli $(24.7 \mathrm{~mm})$, while the lowest $(20.8 \mathrm{~mm})$ was recorded for B. subtilis. This high bactericidal activity of AgNPs is certainly due to the silver cations released from AgNPs that act as reservoirs for the $\mathrm{Ag}^{+}$ bactericidal agent (Dakal et al., 2016). In addition, Agnihotri et al. (2014) reported that the sizes under $30 \mathrm{~nm}$ are more active than bigger nanoparticles. Generally, AgNPs showed higher antibacterial activity against gram-negative bacteria $(E$ coli and $S$. typhimurium) than gram-positive bacteria ( $S$. aureus and B. subtilis). This result is possible due to the difference in the structure of the cell wall between gram-positive and gram-negative bacteria. The more fortified cell wall of the gram-positive bacteria makes it less penetrable compared to the cell membrane of the gramnegative bacteria (Chaloupka et al., 2010).

For antifungal activity, AgNPs showed various degrees of inhibition against the growth of $A$. flavus and $A$. niger. Where, the inhibition zones caused by AgNPs were 17 and $20 \mathrm{~mm}$ for $A$. flavus and $A$. niger, respectively as shown in Fig (3). The antifungal mechanism of AgNPs has been explained as reported by Holt and Bard (2005) and Musa et al. (2018) by the following mechanistic pathways: 1) Owing to their small size, AgNPs can easily uptake by the fungal cells through the disruption of fungal cell walls. 2) AgNPs act as a reservoir for releasing of $\mathrm{Ag}^{+}$ion, causing to cease the ATP production and to stop DNA replication by ROS and hydroxy radicals. As a result, the biochemical cycle of fungal cells was ceased to induce fugal cells death.

\section{Antioxidant activity of silver nanoparticles:}

The free radical scavenging activity of silver nanoparticles was evaluated on the potency to scavenge the synthetic DPPH. The standard ascorbic acid was used to compare with synthesized AgNPs as shown in Table (2).

From Table (2), it could be observed that the antioxidant activity was increased from 25 to $59 \%$ for AgNPs and from 48 to $71 \%$ for ascorbic acid with increasing their concentrations from 25 to $100 \mu \mathrm{g} / \mathrm{ml}$. Also, the antioxidant activity of AgNPs was lower than antioxidant activity of ascorbic acid at all concentrations. The scavenging effect of AgNPs was close to scavenging effect of standard ascorbic acid with equivalent efficiency estimated by $83.1 \%$ at concentration100 $\mu \mathrm{g} / \mathrm{ml}$. In this concern, Mohanta et al. (2017) proved that AgNPs to be very effective scavengers.

Generally, the abovementioned data exhibited good antioxidant potency and suggested the possibility of AgNPs based coating could be effectively employed as new antioxidant materials for application in food processing.

\section{Effect of coating with silver nanoparticles on quality criteria of apricots:}

Weight loss (\%):

Weight loss is mainly associated with respiration and moisture evaporation through the skin. The thin skin of apricot fruits makes them susceptible to rapid loss of water resulting in shriveling and deterioration (Wu et al., 2015). The effect of coating prepared with 250 and 500 ppm silver nanoparticles on weight loss of apricot fruits during storage at room temperature $\left(25 \pm 3^{\circ} \mathrm{C}\right)$ and cold temperature $\left(6 \pm 2^{\circ} \mathrm{C}\right)$ was presented in Table (3). In general, during prolonged storage periods, a gradually increase $(\mathrm{P} \leq 0.05)$ in weight loss $(\%)$ was detected for all tested samples at different temperatures, which might be related to the continuous movement of water from the fruits to the surrounding environment (Duan et al., 2011).

During storage at room temperature $\left(25 \pm 3^{\circ} \mathrm{C}\right)$, the weight loss of coated and uncoated samples (control sample) showed an increasing trend. The weight loss (\%) of control sample was significantly greater $(\mathrm{P} \leq 0.05)$ than coated samples in all stages of storage. After two days of storage, the control sample showed greatest weight loss $(1.88 \%)$ compared to coated samples with AgNPs at 250 and 500 ppm which reached to 1.85 and $1.74 \%$, respectively. After six days of storage, the control sample showed $8.39 \%$ loss in weight, meanwhile apricots coated by AgNPs at levels 250 and 500 ppm were 5.45 and $5.33 \%$, respectively. At the end of storage (the $8^{\text {th }}$ day), control sample was rejected. While, the weight loss of apricot samples coated with 250 and 500 ppm was 6.80 and $6.62 \%$ respectively without significant differences $(p>0.05)$ between them.

Also, weight loss of apricot samples was significantly affected by cold storage period at $6 \pm 2{ }^{\circ} \mathrm{C}$ up to 24 days. The weight loss of all apricot samples was significantly increased by increasing cold storage periods as shown in Table (3). These are in similarity with the findings of Mohamed et al. (2019), who found that the weight loss (\%) increased significantly 
with the increasing cold storage period for apricot fruits. Also, the samples coated with AgNPs showed less weight loss $(\mathrm{P} \leq 0.05)$ than uncoated sample at all stages of cold, except at the $4^{\text {th }}$ day which showed non-significant differences between them. At the end of cold storage (24 days), surely coating formulas significantly reduced $(\mathrm{P} \leq 0.05)$ weight loss in coated samples compared with uncoated sample. Where uncoated apricot was rejected, while apricot samples coated with AgNPs at 250 and 500 ppm recorded weight loss of 8.87 and $8.13 \%$, respectively. At any time of cold storage there were no significant differences $(p>0.05)$ in weight loss between apricot samples coated with 250 and 500 ppm except at 20 and 24 days which showed significant differences $(\mathrm{P} \leq 0.05)$ between them.

Generally, the results were consistent with previous studies showing a reduction in weight loss was due to the effects of coatings, which served as semipermeable barriers against oxygen, carbon dioxide and moisture, thus reducing respiration, water loss and oxidation reactions. In this context, Svagan et al. (2009) reported that the nanoparticles are responsible for creating a zigzag in the film structure, which would hinder the passage of permeates such as $\mathrm{O}_{2}, \mathrm{Co}_{2}$ and water vapor.

\section{Total solid soluble (\%):}

Total soluble solids (TSS) play an important role in affecting fruit quality and consumer acceptability. As reported by Yun et al. (2017) increasing TSS during storage could be due to the conversion of carbohydrates to sugars and other soluble compounds that it was occurred through metabolic processes and decrease in fruit water, which in turn causes an increase in soluble solids concentration. TSS content of apricot samples as affected by coatings with AgNPs during storage at room and cold temperature for different periods are presented in Table (4).

Data showed that the apricot samples stored at room temperature $\left(25 \pm 3^{\circ} \mathrm{C}\right)$ recorded higher values in Brix percentage than those stored at cold temperature $\left(6 \pm 2^{\circ} \mathrm{C}\right)$. Also, from Table (4), no significant differences were recorded in TSS content between the control sample and the treated samples up to the second day of storage, but it differed significantly $(\mathrm{P} \leq 0.05)$ starting from the $4^{\text {th }}$ day of storage. At initial storage, the TSS content was ranged from 11.52 to $11.54 \%$. The fruits with TSS content greater than $10^{\circ}$ Brix are widely accepted among consumers as mentioned by Muzzaffar et al. (2018). Also, it could be observed that the TSS content increased $(\mathrm{P} \leq 0.05)$ during storage periods at different temperatures.

During storage at room temperature, the control sample showed the highest content of TSS at the end of each storage period compared with the coated samples. Where, the TSS content of control sample increased from 11.54 to $15.80 \%$ with incremental rate $36.91 \%$ on the $6^{\text {th }}$ day of storage, compared to 13.96 and $13.77 \%$ for coated samples with AgNPs at 250 and 500 ppm, which showed lower incremental rates (21.18 and $19.43 \%$, respectively) with significant differences $(\mathrm{P} \leq 0.05)$ between them at the same period. At the end of storage (the $8^{\text {th }}$ day), uncoated sample was rejected. While, TSS contents were reached to 14.31 and $14.02 \%$ for apricot samples treated with AgNPs at levels 250 and 500 ppm, respectively. The increase in TSS may be a consequence of cell-wall degradation or the degradation of other polysaccharides present in the fruit. Another elucidation for the observed increase in the TSS is the considerable loss of water during storage (Gol et al., 2013). However, the coated apricots experienced only a very slight increase of TSS and coating was effective in retardation of the metabolic process and oxygen permeation. Also, our results are in agreement with those reported by Wani et al. (2019), who found (during postharvest storage) apricots undergo rise in respiration, which results into an increase in TSS by the loss of water as a result of dehydration during storage.

With regard to the storage of apricot samples on cold temperature $\left(6 \pm 2^{\circ} \mathrm{C}\right)$, the data in Table (4) showed the same trend in increasing TSS from the $4^{\text {th }}$ day onwards. Where TSS content of all samples was increased $(\mathrm{P} \leq 0.05)$ during storage periods. These results are in line with those reported by El-Abbasy et al. (2018), who mentioned that TSS contents of fruits were continuously increased with the progress of cold storage periods. Generally, the rate of increased TSS was lower in the coated samples compared to the uncoated sample. This can also be attributed simultaneously to the reduction of respiration. Additionally, they prevent the increase in TSS content by slowing down the speed of fruit ripening (Gholami et al., 2017). TSS content of uncoated sample increased from 11.54 to $13.68 \%$ at the $12^{\text {th }}$ days then it spoiled on the $16^{\text {th }}$ day. Also, during storage up to the $12^{\text {th }}$ day, it could be observed that the TSS content was increased and reached 13.18 and $12.95 \%$ for samples coated with AgNPs (at 250 and 500 ppm), respectively. With prolonging of storage periods up to the $24^{\text {th }}$ day, 
the samples coated with AgNPs at 250 and 500 ppm recorded 13.61 and $13.63 \%$, respectively.

\section{Titratable acidity content:}

The effect of coating with AgNPs on titratable acidity (TA) content for apricot fruits are presented in Table (5). The titratable acidity ranged from 0.94 to $0.95 \mathrm{~g}$ malic acid $/ 100 \mathrm{~g}$ apricot fruits at initial storage. These results were in good agreement with previous studies that reported TA values of fresh apricots varied from 0.70 to $1.0 \mathrm{~g}$ malic acid/100g (Muzzaffar et al., 2018). In general, during prolonged storage, a gradual decrease in titratable acidity was detected for fruit samples stored at different temperatures. This is may be due to the consumption of organic acids in the breathing process with a slow decrease observed with coated samples (Fagundes et al., 2015).

During storage on ambient temperature $\left(25 \pm 3^{\circ} \mathrm{C}\right)$, TA content in apricots reduced from $0.95,0.94$ and $0.94 \%$ at the initial day to $0.4,0.58$ and $0.59 \%$ on the $6^{\text {th }}$ day, respectively for control and apricots coated with AgNPs 250 and 500ppm. Also, it could be noticed that no significant differences were recorded in titratable acidity content between all apricot samples, but significant differences $(\mathrm{P} \leq 0.05)$ were recorded between uncoated and coated apricots on the $6^{\text {th }}$ day. At the end of storage ( 8 days), titratable acidity content reached 0.47 and $0.49 \%$ for samples treated with AgNPs at 250 and 500 ppm.

With regard to the effect of cold storage at cold temperature of $6 \pm 2^{\circ} \mathrm{C}$, the data showed the same trend in TA reduction from the $4^{\text {th }}$ day onwards as shown in Table (5). After four days of storage, the TA values for control sample reduced to $0.8 \%$, against 0.9 and $0.91 \%$ for the samples coated with AgNPs at levels 250 and 500 ppm, respectively. Starting from the eighth day of storage a significant difference $(P \leq 0.05)$ was observed between coated and uncoated apricots. On the $12^{\text {th }}$ day of storage, the TA content for uncoated fruits reached $0.47 \%$, while the TA content for samples coated with AgNPs at 250 and 500 ppm reached to 0.8 and $0.77 \%$, respectively. On the $16^{\text {th }}$ day, coated apricots recorded 0.69 and $0.7 \%$ (for samples coated with AgNPs at 250 and 500 ppm, respectively), while uncoated sample was rejected. It is worth noting that at the end of cold storage (24 ${ }^{\text {th }}$ day), the decrement rates in TA content were decreased with increasing of nanoparticles concentration in treated samples. These results indicate that the coatings induce retention in TA of the tested samples during the storage.
Previous studies have suggested that the higher acidity loss in uncoated fruits might reflect the use of organic acids as substrates for respiratory metabolism during storage. Also, the results showed that the nano-membrane could inhibit the respiration of samples and slow down the consumption of acid in the physiological metabolic activities of fruits. Thus, effectively slowing down the downward trend of titratable acid and extending the shelf life of the fruits (Zhang et al., 2018).

\section{Effect of coating with AgNPs on carotenoids content:}

Carotenoids are responsible for the apricot color and its change plays a key role in the degradation of total quality and sensory acceptance of fresh fruits (Fratianni et al., 2017). The effect of coating with AgNPs on carotenoids content for apricots was studied and data are presented in Table (6).

From Table, no significant differences were observed between all tested apricots samples at preliminary stages of storage at both $6 \pm 2^{\circ} \mathrm{C}$ and $25 \pm 3^{\circ} \mathrm{C}$, but it differed significantly $(\mathrm{P} \leq 0.05)$ during the remainder of storage periods. The carotenoids content of control sample was found to be $101 \mathrm{mg} / \mathrm{kg}$, against 100.8 and 100.7 $\mathrm{mg} / \mathrm{kg}$ for the treated apricots with AgNPs at levels 250 and 500 ppm at initial storage. These values were similar to those reported by Le Bourvellec et al. (2018).

At the ambient temperature, from Table (6) we noticed that there were significant differences $(\mathrm{P} \leq 0.05)$ between the uncoated sample and coated apricot samples starting from the fourth day of storage. Moreover, the carotenoid content increased with extended storage periods up to the $4^{\text {th }}$ day in all samples. The maximum value was detected in the uncoated sample (121.2), against 117.6 and 117 $\mathrm{mg} / \mathrm{kg}$ for samples coated with AgNPs at 250 and 500 ppm, respectively. On the $6^{\text {th }}$ day of storage, coated samples continuous in increase of carotenoids content while, uncoated sample showed a decrease at this period. The carotenoid contents for control and samples coated with AgNPs at 250 and 500 ppm were $104,123.1$ and $121.8 \mathrm{mg} / \mathrm{kg}$, respectively. At the end of storage (the $8^{\text {th }}$ day), the uncoated sample was spoiled, while the apricot samples coated with AgNPs at different concentrations showed carotenoid contents 123.2 and 123.9 $\mathrm{mg} / \mathrm{kg}$ at the end of storage with non-significant differences between them as shown in Table (6).

With regard to the storage on cold temperature, from Table (6), it can be observed that, up the $24^{\text {th }}$ day, the coated samples with 
AgNPs 250 and 500ppm were continuous progressively increase $(\mathrm{P} \leq 0.05)$ and reached to 135.1 and $144.8 \mathrm{mg} / \mathrm{kg}$, with significant differences $(\mathrm{P} \leq 0.05)$, while uncoated sample showed an increase up to the $8^{\text {th }}$ days and recorded $113 \mathrm{mg} / \mathrm{kg}$ then it showed decrease on the $12^{\text {th }}$ day (103.1) then it was spoiled at the $16^{\text {th }}$ day.

\section{Effect of coating with AgNPs on malondialdehyde concentration:}

The malondialdehyde (MDA) has been used as a direct indicator of cell membrane injury and index of cell oxidative damage during storage (Gao et al., 2016). The effect of coating with AgNPs on MDA concentration in apricots is presented in Table (7). From Table (7), no differences were observed in MDA concentrations at initial storage (MDA concentration found to be $0.92 \mathrm{mmol} / \mathrm{g}$ ), but it differed significantly $(\mathrm{P} \leq 0.05)$ during different storage periods. Also, it can be concluded that the uncoated sample recorded MDA concentration higher than $(\mathrm{P} \leq 0.05)$ those for coated samples at all storage periods. This increment in MDA concentration during storage as a consequence of ripening fruits. To compare the effect of storage temperatures on MDA concentration, the results found that the storage at room temperature $\left(25 \pm 3^{\circ} \mathrm{C}\right)$ led to MDA concentration higher than those for the storage at cold temperature $\left(6 \pm 2^{\circ} \mathrm{C}\right)$.

During storage at room temperature, the MDA concentration significantly increased $(\mathrm{P} \leq 0.05)$. The control sample showed the highest values of MDA at the end of each storage period compared with coated samples. Where the MDA level for uncoated apricot increased from 0.92 to $1.77 \mathrm{mmol} / \mathrm{g}$ on 6 days, while coated samples were increased by lower rates compared to uncoated sample at the same previous storage periods with significant differences $(\mathrm{P} \leq 0.05)$ between them and reached to 1.27 and $1.22 \mathrm{mmol} / \mathrm{g}$ at the end of storage period for samples coated with AgNPs at 250 and 500 ppm, respectively with non-significant differences between them as shown in Table (7). The dramatic increase in MDA concentration in uncoated fruits resulted in soft and pale tissues. These results are in agreement with the previous study by Khalifa et al. (2016), who observed these changes in fruits color and tissue during storage. Also, they found that the coating treatment was improved the membrane integrity and increased the keeping quality.

With regard to the cold storage, Table (7) indicated that the changes of MDA at cold temperature were slower than those changes at room temperature. At cold temperature, due to the decrease in respiration trend, chemical changes in fruit tissue occur slowly. Generally, MDA values of samples were clearly increased $(\mathrm{P} \leq 0.05)$ during storage periods. However, control sample increased from 0.92 to $1.71 \mathrm{~m}$ $\mathrm{mol} / \mathrm{g}$ after 12 days. Moreover, the rate of increase MDA values were lower in coated samples compared to uncoated sample. These results are in line with those reported by Cui et al. (2019), who found that the MDA level constantly increased during the storage. Also, during prolonged storage periods up to the $24^{\text {th }}$ day, the MDA level constantly increased and reached to 1.41 and $1.34 \mathrm{mmol} / \mathrm{g}$ for samples treated with AgNPs at 250 and 500 ppm, respectively with non-significant differences.

Finally, according to these results, the coating with AgNPs could be effective in maintaining lower MDA concentrations during room storage or cold storage. These results suggest that nano-coatings are a promising tool for preventing postharvest oxidative damage during storage.

\section{Effect of coating with AgNPs on visual decay (\%):}

As fruits have low $\mathrm{pH}$, they are more susceptible to fungal attacks than bacterial ones (Muzzaffar et al., 2018). Fungal decay is one of the key factors responsible for postharvest losses. The effect of coating with AgNPs on decay percentage for apricot fruits is presented in Table (8). In general, there has been a marked increase in the number of infected apricots during prolonged storage periods for all samples. However, the coating treatments reduced the decay percentage during storage periods compared to the uncoated sample. These results are in line with those reported by Mohamed et al. (2019).

During storage at room temperature, the visual decay in the control apricots started with $5 \%$ on the $4^{\text {th }}$ day of storage and the infection rate increased with increasing storage periods while the infection percentage recorded $65 \%$ on the $6^{\text {th }}$ day and $90 \%$ at the $8^{\text {th }}$ days of storage. The coated apricot fruits don't appear any infection up to the $4^{\text {th }}$ day. Starting from the $6^{\text {th }}$ day we observed decay in coated apricots, where the fruits coated with AgNPs at 250 and 500 ppm recorded decay \% 15 and 18\%, respectively. At the end of storage (the $8^{\text {th }}$ day), infection percentages increased and reached to 38 and 27\% for fruits coated with AgNPs at 250 and 500 ppm, respectively.

With regard to the storage of apricots on cold temperature, Table (8) indicated that the 
infection rates at cold temperature were slower than those at room temperature. This due to the slow physiological processes at lowtemperature. Similar results were obtained by Cui et al. (2019), who found that the decay rates of the apricots stored at cold temperatures were lower than those stored at $25^{\circ} \mathrm{C}$.

Generally, up to the $12^{\text {th }}$ day of cold storage, no sign of visible decay in coated apricot fruits was observed; in contrast, uncoated fruits showed signs of decay at the $8^{\text {th }}$ day $(15 \%)$ and reached to $65 \%$ infection on the $12^{\text {th }}$ day of storage. Starting from the $16^{\text {th }}$ day we observed decay in coated apricots, where the fruits treated with AgNPs at 250 and 500 ppm showed decay 15 and 10\%, respectively, compared to control which recorded $90 \%$ infection at this period. These results are in similarity with the findings of El-Abbasy et al. (2018), who found that the decay incidence increased gradually with increasing of the cold storage period in apricot fruits. On the $20^{\text {th }}$ day, uncoated fruits were completely decayed (100\%), while apricots coated with AgNPs at 250 and 500 ppm showed 35 and $20 \%$ infection, respectively. At the end of storage (the $24^{\text {th }}$ day), the infection rates in the coated fruits were reached to 64 and $25 \%$ for fruits treated with AgNPs 250 and 500 ppm, respectively. Finally, the better efficiency of AgNPs coating against spoilage was probably due to the antimicrobial activity of these particles.

\section{Effect of washing treatment on silver concentration in treated fruits:}

With the increasing use of nanotechnology in food and consumer products, there is a need for accurate and precise detection for nanoparticles in complex matrices (Leopold et al., 2016). There are emphasized the necessity of washing for raw materials, which not only removed soil residues, adhering dirt's, dusts and lowering microbial loads; but also had efficient role in the removal of some metallic residual. Silver concentration was quantified by inductively coupled plasma-optical emission spectrometry (ICP-OES) in apricots fruit treated with AgNPs solutions before and after the washing process by running water as shown in Fig (4).

From Fig (4), it was verified that the silver concentrations were 3.15 and $4.26 \mathrm{mg} \mathrm{Ag} \mathrm{kg-1}^{-1}$ for apricot samples coated with 250 and 500 ppm AgNPs, respectively, at initial storage. These concentrations reduced after the end storage period at room temperature to 2.87 and $4.13 \mathrm{mg} \mathrm{Ag} \mathrm{kg}^{-1}$ in the unwashed samples (with reduction ratios 8.89 and $3.05 \%$, respectively).
Also, these initial concentrations reduced to 2.94 and $3.99 \mathrm{mg} \mathrm{Ag} \mathrm{kg}^{-1}$ in the unwashed samples (with reduction ratios 6.76 and $6.33 \%$, respectively) after 24 days of cold storage. This result may be explained by the conversion of metallic silver $\left(\mathrm{Ag}^{0}\right)$ into ionic silver $\left(\mathrm{Ag}^{+}\right)$ which was then released from nanoparticles (Damm and Münstedt, 2008; Kumar-Krishnan et al., 2015 and Marchiore et al., 2017).

With regard to the effect of the washing process, Figs (4) and (5) showed the effect of washing process by running water on the silver concentration of apricot samples coated with AgNPs at different levels. As a general trend, the washing process of coated apricot fruits after storing them at previously mentioned periods led to almost complete removal for silver particles by rates ranged from 99.10 to $99.29 \%$.

From Figs (4) and (5), it can be concluded that the silver concentrations of fruits stored for 8 days at room temperature were decreased from 2.87 and $4.13 \mathrm{mg} \mathrm{Ag} \mathrm{kg}^{-1}$ to 0.026 and 0.035 mg Ag kg-1 after washing (with reduction ratios 99.1 and $99.15 \%$ ) for samples coated with 250 and 500 ppm AgNPs, respectively. While, the silver concentrations of fruits stored for 24 days at cold temperature were decreased from 2.94 and $3.99 \mathrm{mg} \mathrm{Ag} \mathrm{kg}^{-1}$ to 0.021 and $0.029 \mathrm{mg} \mathrm{Ag}$ $\mathrm{kg}^{-1}$ after washing (with reduction ratios 99.29 and $99.28 \%$ ) for samples coated with 250 and 500 ppm AgNPs, respectively.

Generally, short or long-term dietary investigations with AgNPs are not available, 28-90-day gavage dosing studies with nanosilver indicate No Observed Adverse Effect Levels for traditional toxicological endpoints ranges from 0.5- 500 mg Ag/kg/d (ToxConsult 2016). Also, the levels detected in coated apricot samples after washing treatment were below the oral reference dose for silver in human of $0.005 \mathrm{mg} / \mathrm{kg} / \mathrm{d}$ equivalent $0.35 \mathrm{mg} \mathrm{Ag}$ per person $(70 \mathrm{~kg}$ ) /day (WHO 2011).

\section{Effect of coating with AgNPs on the apricots shelf-life:}

The most important advantage of any antimicrobial technology is the ability to extend the shelf life of the food system (Moradinezhad and Jahani 2019). In general, the shelf life qualities of fruits stored at cold temperature $\left(6 \pm 2^{\circ} \mathrm{C}\right)$ were better than that stored at room temperature $\left(25 \pm 3^{\circ} \mathrm{C}\right)$. Data presented in Fig. (6) revealed that the coating treatment of apricot fruits can modify their spoilage profile and extend the shelf-life. The shelf life of apricots was evaluated visually from the surface color changes and infected spots. For instance, the 
control sample (uncoated fruits) spoiled after 4 days of storage at room temperature and after 8 days of storage at cold temperature. While, both treated samples with AgNPs at 250 and 500 ppm extended their shelf life to eight days at room temperature. It is worth noting that the coating treatment led to increasing the shelf life of fruits coated with AgNPs at 250 and 500 ppm to 20 and 24 days, respectively at cold temperature as shown in Fig (6). These results are important economically and have very promising effects for apricot producers.

\section{CONCLUSION}

Coatings represent one of the most important methods being used for preserving the quality of fruits and vegetables. Nanoscale materials have emerged as novel antimicrobial agents, where nanoparticles of silver were effective against tested pathogenic microorganisms. The application of AgNPs appears to be highly promising in the field of food processing for extending the shelf life of apricots during storage. Based on comprehensive comparison and evaluation, apricots coated by AgNPs could be kept in good quality for 24 days at $6^{\circ} \mathrm{C}$ and for 8 days at $25^{\circ} \mathrm{C}$.

\section{REFERENCES}

A.O.A.C., 2016. Official Methods of Analysis of the Association of Official Analytical Chemists International (20 th Edition). Maryland, USA.

A.P.H.A., A.W.W.A., W.E.F., 2017. American Public Health Association, American Water Works Association, and Water Environment Federation. Standard Methods for the Examination of Water and Wastewater, $23^{\text {rd }}$ ed. (Rice, E. W., Baird, R. B., Eaton, A. D., Clesceri, L. S.) Washington DC.

Aadil, K.R., Mussatto, S.I., Jha, H., 2018. Synthesis and characterization of silver nanoparticles loaded poly (vinyl alcohol)-lignin electrospun nanofibers and their antimicrobial activity. Int. J. Biol. Macromol., 120, 763-767.

Abd-Elwahab, S.M., 2015. Apricot postharvest fruit quality, storability and marketing in response to pre-harvest application. Middle East J. Agric. Res., 4 (2), 347-358.

Agnihotri, S., Mukherji, S., Mukherji, S., 2014. Sizecontrolled silver nanoparticles synthesized over the range 5-100 nm using the same protocol and their antibacterial efficacy. RSC Adv., 4 (8), 3974-3983.

Akin, E.B., Karabulut, I., Topcu, A., 2008. Some compositional properties of main Malatya apricot (Prunus armeniaca L.) varieties. Food Chem., 107 (2), 939-948.
Anjum, S., Jacob, G., Gupta, B., 2019. Investigation of the herbal synthesis of silver nanoparticles using Cinnamon zeylanicum extract. Emerg. Mater., 2 (1), 113-122.

Bakhy, E.A., Zidan, N.S., Aboul-Anean, H.E.D., 2018. The effect of nano materials on edible coating and films' improvement. Int. J. Pharm. Res. Allied Sci., 7 (3), 20-41.

Balouiri, M., Sadiki, M., Ibnsouda, S.K., 2016. Methods for in vitro evaluating antimicrobial activity: A review. J. pharm. Anal., 6 (2), 71-79.

Chaloupka, K., Malam, Y., Seifalian, A.M., 2010. Nanosilver as a new generation of nanoproduct in biomedical applications. Trends Biotechnol., 28 (11), 580-588.

Chandirika, J.U., Selvi, S.T., Annadurai, G., 2018. Synthesis and characterization of silver nanoparticle using Melia azedarach for vegetable coating and antibacterial activity. Journal of Innov. Pharm. Biol. Sci., 5 (2), 38-42.

Costat, 1986. Costat-Statistics Software Powerful. Easy to use. Reasonably priced. Available from: http://cohort.com/costat.html. CoHort Software, 798 Lighthouse Ave. PMB 320 Monterey, CA 93940, U.S.A.

Cui, K., Zhao, H., Sun, L., Yang, L., Cao, J., Jiang, W., 2019. Impact of near freezing temperature storage on postharvest quality and antioxidant capacity of two apricot (Prunus armeniaca L.) cultivars. J. Food Biochem., e12857.

Dakal, T.C., Kumar, A., Majumdar, R.S., Yadav, V., 2016. Mechanistic basis of antimicrobial actions of silver nanoparticles. Front. Microbiol., 7, 1831.

Damm, C., Münstedt, H., 2008. Kinetic aspects of the silver ion release from antimicrobial polyamide/silver nanocomposites. Appl. Phys. A, 91 (3), 479-486.

Duan, J., Wu, R., Strik, B.C., Zhao, Y., 2011. Effect of edible coatings on the quality of fresh blueberries (Duke and Elliott) under commercial storage conditions. Postharvest Biol. Technol., 59 (1), 71-79.

El-Abbasy, U.K., El-Khalek, A.A., Mohamed, M.I., 2018. Postharvest applications of 1methylcyclopropene and salicylic acid for maintaining quality and enhancing antioxidant enzyme activity of apricot fruits cv. 'Canino' During cold storage. Egypt. J. Hort., 45, 1-23.

El-Rafie, M.H., Ahmed, H.B., Zahran, M.K., 2014. Facile precursor for synthesis of silver nanoparticles using alkali treated maize starch. Int. Sch. Res. Notices, 702396.

Fagundes, C., Moraes, K., Pérez-Gago, M.B., Palou, L., Maraschin, M., Monteiro, A.R., 2015. Effect of active modified atmosphere and cold storage on the postharvest quality of cherry tomatoes. Postharvest Biol. Technol., 109, 73-81. 
FAOSTAT, 2018. FAOSTAT Statistics Database. Cited from: http://faostat3.fao.org.

Fratianni, A., Niro, S., Messia, M.C., Cinquanta, L., Panfili, G., Albanese, D., Di Matteo, M., 2017. Kinetics of carotenoids degradation and furosine formation in dried apricots (Prunus armeniaca L.). Food Res. Int., 99, 862-867.

Gao, H., Zhang, Z.K., Chai, H.K., Cheng, N., Yang, Y., Wang, D.N., Cao, W., 2016. Melatonin treatment delays postharvest senescence and regulates reactive oxygen species metabolism in peach fruit. Postharvest Biol. Technol., 118, 103110.

Garcia-Ruiz, A., Crespo, J., Lopez-de-Luzuriaga, J.M., Olmos, M.E., Monge, M., RodriguezAlfaro, M.P., Moreno-Arribas, M.V., 2015. Novel biocompatible silver nanoparticles for controlling the growth of lactic acid bacteria and acetic acid bacteria in wines. Food Control. 50, 613-619.

Gholami, R., Ahmadi, E., Farris, S., 2017. Shelf life extension of white mushrooms (Agaricus bisporus) by low temperatures conditioning, modified atmosphere, and nanocomposite packaging material. Food Packag. Shelf Life, 14, 88-95.

Gil-Sánchez, I., Monge, M., Miralles, B., Armentia, G., Cueva, C., Crespo, J., Moreno-Arribas, M.V., 2019. Some new findings on the potential use of biocompatible silver nanoparticles in winemaking. Innov. Food Sci. Emerg. Technol., 51, 64-72.

Gol, N.B., Patel, P.R., Rao, T.R., 2013. Improvement of quality and shelf-life of strawberries with edible coatings enriched with chitosan. Postharvest Biol. Technol., 85, 185195.

Gordienko, M.G., Palchikova, V.V., Kalenov, S.V., Belov, A.A., Lyasnikova, V.N., Poberezhniy, D.Y., Skladnev, D.A., 2019. Antimicrobial activity of silver salt and silver nanoparticles in different forms against microorganisms of different taxonomic groups. J. Hazard. Mater., 378, 120754.

Hajji, S., Younes, I., Affes, S., Boufi, S., Nasri, M., 2018. Optimization of the formulation of chitosan edible coatings supplemented with carotenoproteins and their use for extending strawberries postharvest life. Food hydrocoll., 83, 375-392.

Hebeish, A., Shaheen, T.I., El-Naggar, M.E., 2016. Solid state synthesis of starch-capped silver nanoparticles. Int. J. Biol. Macromol., 87, 70-76.

Holt, K.B., Bard, A.J., 2005. Interaction of silver (I) ions with the respiratory chain of Escherichia coli: an electrochemical and scanning electrochemical microscopy study of the antimicrobial mechanism of micromolar Ag+. Biochemistry, 44 (39), 13214-13223.
Khalifa, I., Barakat, H., El-Mansy, H.A., Soliman, S.A., 2016. Effect of chitosan-olive oil processing residues coatings on keeping quality of cold-storage strawberry (Fragaria ananassa. Var. Festival). J. Food Qual., 39 (5), 504-515.

Kowsalya, E., MosaChristas, K., Balashanmugam, P., Rani, J.C., 2019. Biocompatible silver nanoparticles/poly (vinyl alcohol) electrospun nanofibers for potential antimicrobial food packaging applications. Food Packag. Shelf Life, 21, 100379.

Kraśniewska, K., Galus, S., Gniewosz, M., 2020. Biopolymers-based materials containing silver nanoparticles as active packaging for food applications-A review. Int. J. Mol. Sci., 21 (3), 698.

Kumar, S., Ye, F., Dobretsov, S., Dutta, J., 2019. Chitosan nanocomposite coatings for food, paints, and water treatment applications. Appl. Sci., 9 (12), 2409.

Kumar-Krishnan, S., Prokhorov, E., HernándezIturriaga, M., Mota-Morales, J.D., VázquezLepe, M., Kovalenko, Y., Luna-Bárcenas, G., 2015. Chitosan/silver nanocomposites: Synergistic antibacterial action of silver nanoparticles and silver ions. Eur. Polym. J., 67, 242-251.

Le Bourvellec, C., Gouble, B., Bureau, S., Reling, P., Bott, R., Ribas-Agusti, A., Renard, C.M., 2018. Impact of canning and storage on apricot carotenoids and polyphenols. Food Chem., 240, 615-625.

Leopold, K., Philippe, A., Wörle, K., Schaumann, G.E., 2016. Analytical strategies to the determination of metal-containing nanoparticles in environmental waters. TracTrends Anal. Chem., 84, 107-120.

Li, J., Fu, Y., Yan, J., Song, H., Jiang, W., 2019. Forced air precooling enhanced storage quality by activating the antioxidant system of mango fruits. J. Food Qual., 1606058.

Liu, H., Jiang, W., Cao, J., Ma, L., 2018. A combination of 1-methylcyclopropene treatment and intermittent warming alleviates chilling injury and affects phenolics and antioxidant activity of peach fruit during storage. Sci. Hort., 229, 175-181.

Majid, I., Nayik, G.A., Dar, S.M., Nanda, V., 2016. Novel food packaging technologies: Innovations and future prospective. J. Saudi Soc. Agric. Sc., 17 (4), 454-462.

Marchiore, N.G., Manso, I.J., Kaufmann, K.C., Lemes, G.F., de Oliveira Pizolli, A.P., Droval, A.A., Leimann, F.V., 2017. Migration evaluation of silver nanoparticles from antimicrobial edible coating to sausages. LWT-Food Sci. Technol., 76, 203-208.

Mohamed, M.A., Gehan, A.M., Rania, A.M., 2019. Effect of edible coating on storability and 
quality of apricot fruits. J. Hort. Sci. Ornamen. Plants. 11 (1), 38-51.

Mohanta, Y.K., Panda, S.K., Jayabalan, R., Sharma, N., Bastia, A.K., Mohanta, T.K., 2017. Antimicrobial, antioxidant and cytotoxic activity of silver nanoparticles synthesized by leaf extract of Erythrina suberosa (Roxb.). Front. Mol. Biosc., 4, 14-23.

Mokhena, T.C., Luyt, A.S., 2017. Electrospun alginate nanofibres impregnated with silver nanoparticles: Preparation, morphology and antibacterial properties. Carbohyd. Polym., 165, 304-312.

Mondal, M.F., 2000. Production and Storage of Fruits (in Bangla). Mrs. Afia Mondal, BAU Campus, Mymensingh, pp-2202, 2212.

Monge, M., Moreno-Arribas, M.V., 2016. Applications of nanotechnology in wine production and quality and safety control. In: Moreno-Arribas, M.V., Bartolome Sualdea, B. (Eds.), Wine Safety, Consumer Preference, and Human Health. Springer International Publishing, pp. 51-69.

Moradinezhad, F., Jahani, M., 2019. Effect of potassium permanganate, 1Methylcyclopropene and modified atmosphere packaging on postharvest losses and quality of fresh apricot cv. Shahroudi. J. Hort. Postharvest Res., 2, 39-48.

Musa, S.F., Yeat, T.S., Kamal, L.Z.M., Tabana, Y.M., Ahmed, M.A., El Ouweini, A., Sandai, D., 2018. Pleurotus sajor-caju can be used to synthesize silver nanoparticles with antifungal activity against Candida albicans. J. Sci. Food Agric., 98 (3), 1197-1207.

Muzzaffar, S., Bhat, M.M., Wani, T.A., Wani, I.A., Masoodi, F.A., 2018. Postharvest biology and technology of apricot. In: Postharvest Biology and Technology of Temperate Fruits. Springer, Cham., pp. 201-222.

Onitsuka, S., Hamada, T., Okamura, H., 2019. Preparation of antimicrobial gold and silver nanoparticles from tea leaf extracts. Colloids and Surfaces B: Biointerfaces, 173, 242-248.

Ortiz-Duarte, G., Pérez-Cabrera, L.E., ArtésHernández, F., Martínez-Hernández, G.B., 2019. Ag-chitosan nanocomposites in edible coatings affect the quality of fresh-cut melon. Postharvest Biol. Technol., 147, 174-184.

Qin, Y., Liu, D., Wu, Y., Yuan, M., Li, L., Yang, J., 2015. Effect of PLA/PCL/cinnamaldehyde antimicrobial packaging on physicochemical and microbial quality of button mushroom (Agaricus bisporus). Postharvest Biol. Technol., 99, 73-79.

Saravanakumar, K., Hu, X., Chelliah, R., Oh, D.H., Kathiresan, K., Wang, M.H., 2020. Biogenic silver nanoparticles-polyvinylpyrrolidone based glycerosomes coating to expand the shelf life of fresh-cut bell pepper (Capsicum annuum L. var. grossum (L.) Sendt). Postharvest Biol. Technol., 160, 111039.

Sharma, P., Shehin, V.P., Kaur, N., Vyas, P., 2019. Application of edible coatings on fresh and minimally processed vegetables: a review. Int. J. Veg. Sci., 25 (3), 295-314.

Sundararajan, B, Mahendran, G, Thamaraiselvi R., Ranjitha kumari, B.D., 2016. Biological activities of synthesized silver nanoparticles from Cardiospermum halicacabum L. Ind. Acad. Sci., 39, (2), 423-431.

Svagan, A.J., Hedenqvist, M.S., Berglund, L., 2009. Reduced water vapour sorption in cellulose nanocomposites with starch matrix. Compos. Sci. Technol., 69 (3-4), 500-506.

Swaminathan, M.S., 2016. Food losses and food waste. In: Combating Hunger and Achieving Food Security. Cambridge University Press: Cambridge, UK, pp-37-46.

ToxConsult Pty Ltd., 2016. Potential Health Risks Associated with Nanotechnologies in Existing Food Additives. Technical report prepared for FSANZ. ToxConsult Report Number: ToxCR230215-RF2. 13 $3^{\text {th }}$ May 2016.

W.H.O., 2011. World Health Organization. Guidelines for drinking-water quality. $4^{\text {th }}$ Ed., Geneva.

Wang, Z., Ma, L., Zhang, X., Xu, L., Cao, J., Jiang, W., 2015. The effect of exogenous salicylic acid on antioxidant activity, bioactive compounds and antioxidant system in apricot fruit. Sci. Hort., 181, 113-120.

Wani, S.M., Gull, A., Wani, T.A., Masoodi, F.A., Ganaie, T.A., 2019. Effect of edible coating on the shelf life enhancement of apricot (Prunus armeniaca L.). J. Postharvest Technol., 5 (3), 2634.

Wasiu Oluwatofarati, S., Akeem Olayemi, R., Rahman, A. 2018. Effects of silver bionanoparticle treatment on the wet preservation, technological, and chemical qualities of meat. Food Qual. Saf., 2 (3), 159-164.

Wu, B., Guo, Q., Wang, G.X., Peng, X.Y., Che, F.B., 2015. Effects of different postharvest treatments on the physiology and quality of 'Xiaobai' apricots at room temperature. J. Food Sci. Technol., 52 (4), 2247-2255.

Xing, Y., Li, W., Wang, Q., Li, X., Xu, Q., Guo, X., Yang, H., 2019. Antimicrobial nanoparticles incorporated in edible coatings and films for the preservation of fruits and vegetables. Molecules, 24 (9), 1695.

Yun, X., Wang, Y., Li, M., Jin, Y., Han, Y., Dong, T. 2017. Application of permselective poly ( $\varepsilon$ caprolactone) film for equilibrium-modified atmosphere packaging of strawberry in cold storage. J. Food Proc. Preserv., 41 (6), e13247. 
Zambrano-Zaragoza, M., González-Reza, R., Mendoza-Muñoz, N., Miranda-Linares, V., Bernal-Couoh, T., Mendoza-Elvira, S., Quintanar-Guerrero, D., 2018. Nanosystems in edible coatings: A novel strategy for food preservation. Int. J. Mol. Sci., 19 (3), 705.
Zhang, C., Li, W., Zhu, B., Chen, H., Chi, H., Li, L., Xue, J., 2018. The quality evaluation of postharvest strawberries stored in nano-Ag packages at refrigeration temperature. Polymers, 10 (8), 894.

Table 1. The operating conditions for the determination of silver ions using ICP-OES.

\begin{tabular}{lc}
\hline Operating conditions & Silver ions \\
\hline Wave length & 328.068 \\
Intensity & 82675 \\
Radio Frequency (RF) Plasma Torches power & 1.2 \\
$\mathrm{~kW}$ & \\
Nebulizer flow (L/min) & 0.7 \\
Plasma flow (L/min) & 12 \\
Viewing mode & Axial \\
Background Correction & Fitted \\
Correlation Coefficient & 0.98 \\
Calibration error & $10 \%$ \\
Calibration Fit & Rational \\
Limit of quantification (ug/dl) & 5 \\
\hline
\end{tabular}

Table 2. DPPH-free radical scavenging activity (\%) of synthesized AgNPs compared to ascorbic acid:

\begin{tabular}{cccc} 
Concentration $(\boldsymbol{\mu g} / \mathbf{m L})$ & AgNPs & Ascorbic acid & Equivalent efficiency $(\%)$ \\
\hline $\mathbf{2 5}$ & 25 & 48 & 52.08 \\
$\mathbf{5 0}$ & 41 & 56 & 73.21 \\
$\mathbf{7 5}$ & 50 & 63 & 79.36 \\
$\mathbf{1 0 0}$ & 59 & 71 & 83.10 \\
\hline
\end{tabular}

Table 3. Effect of coating with AgNPs on weight loss (\%) of apricots during storage at ambient temperature $\left(25 \pm 3^{\circ} \mathrm{C}\right)$ and cold temperature $\left(6 \pm 2^{\circ} \mathrm{C}\right)$ :

\begin{tabular}{|c|c|c|c|c|c|c|c|c|c|c|c|}
\hline \multirow{2}{*}{\multicolumn{2}{|c|}{ Treatment }} & \multicolumn{4}{|c|}{ Storage (day) at $25 \pm 3^{\circ} \mathrm{C}$} & \multicolumn{6}{|c|}{ Storage (day) at $6 \pm 2^{\circ} \mathrm{C}$} \\
\hline & & 2 & 4 & 6 & 8 & 4 & 8 & 12 & 16 & 20 & 24 \\
\hline \multicolumn{2}{|c|}{ Control } & $1.88 \mathrm{Ca}$ & $4.65^{\text {Ва }}$ & 8.39Аа & $\mathrm{ND}$ & $1.20^{\mathrm{Ca}}$ & $3.98^{\text {ва }}$ & $6.50^{\mathrm{Aa}}$ & ND & ND & ND \\
\hline AgNPs & 250 & $1.85^{\mathrm{Da}}$ & $3.48^{\mathrm{Cb}}$ & $5.45^{\mathrm{Bb}}$ & $6.80^{\mathrm{Aa}}$ & $1.13^{\mathrm{Fa}}$ & $2.83^{\mathrm{Eb}}$ & $4.01^{\mathrm{Db}}$ & $5.37 \mathrm{Ca}$ & $6.51^{\mathrm{Ba}}$ & $8.87^{\mathrm{A} a}$ \\
\hline ppm & 500 & $1.74^{\mathrm{Da}}$ & $3.41^{\mathrm{Cb}}$ & $5.33^{\mathrm{Bb}}$ & $6.62^{\mathrm{Aa}}$ & $1.16^{\mathrm{Fa}}$ & $2.81^{\mathrm{Eb}}$ & $3.94^{\mathrm{Db}}$ & $5.20^{\mathrm{Ca}}$ & $6.29 \mathrm{Bb}$ & $8.13^{\mathrm{Ab}}$ \\
\hline
\end{tabular}

Means values in the same row (as a capital letter) or column (as a small letter) with different letters are significantly different $(\mathrm{p} \leq 0.05)$. 
Table 4. Effect of coating with AgNPs on total soluble solids (\%) for apricots during storage at ambient temperature $\left(25 \pm 3^{\circ} \mathrm{C}\right)$ and cold temperature $\left(6 \pm 2^{\circ} \mathrm{C}\right)$ :

\begin{tabular}{|c|c|c|c|c|c|c|c|c|c|c|c|c|c|}
\hline \multirow{2}{*}{\multicolumn{2}{|c|}{ Treatment }} & \multicolumn{5}{|c|}{ Storage (day) at $25 \pm 3^{\circ} \mathrm{C}$} & \multicolumn{7}{|c|}{ Storage (day) at $6 \pm 2^{\circ} \mathrm{C}$} \\
\hline & & $\mathbf{0}$ & 2 & 4 & 6 & 8 & 0 & 4 & 8 & 12 & 16 & 20 & 24 \\
\hline \multicolumn{2}{|c|}{ Control } & $11.54^{\mathrm{Da}}$ & $13.11 \mathrm{Ca}$ & $14.87^{\mathrm{Ba}}$ & $15.80^{\mathrm{Aa}}$ & ND & $11.54^{\mathrm{Ca}}$ & $12.28^{\mathrm{Ba}}$ & $13.23^{\mathrm{Aa}}$ & $13.68^{\mathrm{Aa}}$ & ND & ND & ND \\
\hline AgNPs & 250 & $11.52 \mathrm{Ca}$ & $12.92^{\mathrm{Ba}}$ & $13.41^{\mathrm{ABb}}$ & $13.96^{\mathrm{Ab}}$ & 14.31 Аa & $11.52^{\mathrm{Ca}}$ & $12.11^{\mathrm{BCa}}$ & $12.77 \mathrm{ABa}$ & $13.18^{\mathrm{Aa}}$ & $13.45^{\text {Аа }}$ & 13.49Аа & $13.61^{\mathrm{Aa}}$ \\
\hline Ppm & 500 & $11.53 \mathrm{Ca}$ & $12.80^{\text {ва }}$ & $13.38 \mathrm{ABb}$ & $13.77^{\mathrm{Ab}}$ & $14.02^{\mathrm{Aa}}$ & $11.53 \mathrm{Da}$ & $12.08 \mathrm{CDa}$ & $12.51^{\mathrm{BCa}}$ & $12.95^{\mathrm{ABa}}$ & 13.21 $\mathrm{Aa}$ & 13.62 Аа & $13.63^{\mathrm{Aa}}$ \\
\hline
\end{tabular}

Means values in the same row (as a capital letter) or column (as a small letter) with different letters are significantly different $(\mathrm{p} \leq 0.05)$ ND: Not determined AgNPs: silver nanoparticles.

Table 5. Effect of coating with AgNPs on total acidity (g malic acid/100g) for apricots during storage at ambient temperature $\left(25 \pm 3^{\circ} \mathrm{C}\right)$ and cold temperature $\left(6 \pm 2^{\circ} \mathrm{C}\right)$ :

\begin{tabular}{|c|c|c|c|c|c|c|c|c|c|c|c|c|c|}
\hline \multirow{2}{*}{\multicolumn{2}{|c|}{ Treatment }} & \multicolumn{5}{|c|}{ Storage (day) at $25 \pm 3^{\circ} \mathrm{C}$} & \multicolumn{7}{|c|}{ Storage (day) at $6 \pm 2^{\circ} \mathrm{C}$} \\
\hline & & $\mathbf{0}$ & 2 & 4 & 6 & 8 & $\mathbf{0}$ & 4 & 8 & 12 & 16 & 20 & 24 \\
\hline \multicolumn{2}{|c|}{ Control } & $0.95^{\mathrm{Aa}}$ & $0.76^{\mathrm{Ba}}$ & $0.62^{\mathrm{Ba}}$ & $0.40^{\mathrm{Cb}}$ & ND & $0.95^{\mathrm{Aa}}$ & $0.80^{\mathrm{Aa}}$ & $0.62^{\mathrm{Bb}}$ & $0.47^{\mathrm{Bb}}$ & ND & ND & ND \\
\hline \multirow{2}{*}{$\begin{array}{l}\text { AgNPs } \\
\text { Ppm }\end{array}$} & 250 & $0.94^{\mathrm{Aa}}$ & $0.81^{\mathrm{ABa}}$ & $0.70^{\mathrm{BCa}}$ & $0.58^{\mathrm{CDa}}$ & $0.47^{\mathrm{Da}}$ & $0.94^{\mathrm{Aa}}$ & $0.90^{\mathrm{Aa}}$ & $0.84^{\mathrm{ABa}}$ & $0.80^{\mathrm{ABa}}$ & $0.69^{\mathrm{BCa}}$ & $0.57^{\mathrm{Ca}}$ & $0.45^{\mathrm{Da}}$ \\
\hline & 500 & $0.94^{\mathrm{Aa}}$ & $0.80^{\mathrm{ABa}}$ & $0.71^{\mathrm{BCa}}$ & $0.59^{\mathrm{CDa}}$ & $0.49^{\mathrm{Da}}$ & $0.94^{\mathrm{Aa}}$ & $0.91^{\mathrm{Aa}}$ & $0.86^{\mathrm{ABa}}$ & $0.77^{\mathrm{ABCa}}$ & $0.70^{\mathrm{BCa}}$ & $0.61^{\mathrm{CDa}}$ & $0.49^{\mathrm{Da}}$ \\
\hline
\end{tabular}

Means values in the same row (as a capital letter) or column (as a small letter) with different letters are significantly different $(\mathrm{p} \leq 0.05)$ ND: Not determined AgNPs: silver nanoparticles.

Table 6. Effect of coating with AgNPs on the total carotenoids content (mg/kg FM) during storage at ambient temperature $\left(25 \pm 3^{\circ} \mathrm{C}\right)$ and cold temperature $\left(6 \pm 2^{\circ} \mathrm{C}\right)$ :

\begin{tabular}{|c|c|c|c|c|c|c|c|c|c|c|c|c|c|}
\hline \multirow{2}{*}{\multicolumn{2}{|c|}{ Treatment }} & \multicolumn{5}{|c|}{ Storage (day) at $25 \pm 3^{\circ} \mathrm{C}$} & \multicolumn{7}{|c|}{ Storage (day) at $6 \pm 2^{\circ} \mathrm{C}$} \\
\hline & & 0 & 2 & 4 & 6 & 8 & 0 & 4 & 8 & 12 & 16 & 20 & 24 \\
\hline \multicolumn{2}{|c|}{ Control } & $101.0^{\mathrm{Ca}}$ & $107.2^{\mathrm{Ba}}$ & $121.2^{\mathrm{Aa}}$ & $104.0^{\mathrm{BCb}}$ & ND & $101.0^{\mathrm{Ca}}$ & $105.3^{\mathrm{Ba}}$ & $113.0^{\mathrm{Aa}}$ & $103.1^{\mathrm{BCb}}$ & ND & ND & ND \\
\hline \multirow{2}{*}{$\begin{array}{l}\text { AgNPs } \\
\text { Ppm }\end{array}$} & 250 & $100.8^{\mathrm{Da}}$ & $105.6^{\mathrm{Ca}}$ & 117.6 $6^{\mathrm{Bab}}$ & $123.1^{\mathrm{Aa}}$ & $123.2^{\mathrm{Aa}}$ & $100.8^{\mathrm{Ea}}$ & $103.8^{\text {Еа }}$ & $107.7 \mathrm{Db}$ & $116.6^{\mathrm{Ca}}$ & $127.4^{\mathrm{Ba}}$ & $134.2^{\mathrm{Aa}}$ & $135.1^{\mathrm{Ab}}$ \\
\hline & 500 & $100.7 \mathrm{Da}$ & $105.3 \mathrm{Ca}$ & $117.0^{\mathrm{Bb}}$ & $121.8^{\mathrm{Aa}}$ & $123.9^{\text {Аа }}$ & $100.7 \mathrm{Fa}$ & $104.0 \mathrm{EFa}$ & $107.5^{\mathrm{Eb}}$ & $114.9^{\mathrm{Da}}$ & $125.0^{\mathrm{Ca}}$ & $133.4^{\mathrm{Ba}}$ & $144.8^{\mathrm{Aa}}$ \\
\hline
\end{tabular}

Means values in the same row (as a capital letter) or column (as a small letter) with different letters are significantly different $(\mathrm{p} \leq 0.05)$ ND: Not determined AgNPs: silver nanoparticles.

Table 7. Effect of coating with AgNPs on the malondialdehyde concentration (mmol/g) of apricots during storage at ambient temperature $\left(25 \pm 3^{\circ} \mathrm{C}\right)$ and cold temperature $\left(6 \pm 2^{\circ} \mathrm{C}\right)$ :

\begin{tabular}{|c|c|c|c|c|c|c|c|c|c|c|c|c|c|}
\hline \multirow{2}{*}{\multicolumn{2}{|c|}{ Treatment }} & \multicolumn{5}{|c|}{ Storage (day) at $25 \pm 3^{\circ} \mathrm{C}$} & \multicolumn{7}{|c|}{ Storage (day) at $6 \pm 2^{\circ} \mathrm{C}$} \\
\hline & & $\mathbf{0}$ & 2 & 4 & 6 & 8 & $\mathbf{0}$ & 4 & 8 & 12 & 16 & 20 & 24 \\
\hline \multicolumn{2}{|c|}{ Control } & $0.92^{\mathrm{Da}}$ & $0.99^{\mathrm{Ca}}$ & $1.28^{\mathrm{Ba}}$ & $1.77^{\mathrm{Aa}}$ & ND & $0.92^{\mathrm{Ca}}$ & $0.96^{\mathrm{Ca}}$ & $1.25^{\mathrm{Ba}}$ & $1.71^{\mathrm{Aa}}$ & ND & ND & ND \\
\hline \multirow{2}{*}{$\begin{array}{c}\text { AgNPs } \\
\text { Ppm }\end{array}$} & 250 & $0.92^{\mathrm{Ba}}$ & $0.95^{\mathrm{Ba}}$ & $1.02^{\mathrm{ABb}}$ & $1.13^{\mathrm{ABb}}$ & $1.27^{\mathrm{Aa}}$ & $0.92^{\mathrm{Ca}}$ & $0.93^{\mathrm{Ca}}$ & $0.99 \mathrm{~B}^{\mathrm{Cb}}$ & $1.08^{\mathrm{BCb}}$ & $1.19^{\mathrm{Aa}}$ & $1.38^{\mathrm{Aa}}$ & $1.41^{\mathrm{Aa}}$ \\
\hline & 500 & $0.92^{\mathrm{Ba}}$ & $0.92^{\mathrm{Ba}}$ & $0.98^{\mathrm{Bb}}$ & $1.09^{\mathrm{ABb}}$ & $1.22^{\mathrm{Aa}}$ & $0.92^{\mathrm{Ca}}$ & $0.92^{\mathrm{Ca}}$ & $0.95^{\mathrm{Cb}}$ & $1.01^{\mathrm{BCb}}$ & $1.08^{\mathrm{BCa}}$ & $1.17^{\mathrm{Aa}}$ & $1.34^{\mathrm{Aa}}$ \\
\hline
\end{tabular}

Means values in the same row (as a capital letter) or column (as a small letter) with different letters are significantly different $(\mathrm{p} \leq 0.05)$. 
Table 8. Effect of coating with AgNPs on visual decay (\%) for apricots during storage at room temperature $\left(25 \pm 3^{\circ} \mathrm{C}\right)$ and cold temperature $\left(6 \pm 2^{\circ} \mathrm{C}\right)$ :

\begin{tabular}{|c|c|c|c|c|c|c|c|c|c|c|c|c|c|}
\hline \multirow{2}{*}{\multicolumn{2}{|c|}{ Treatment }} & \multicolumn{5}{|c|}{ Storage (day) at $25 \pm 3^{\circ} \mathrm{C}$} & \multicolumn{7}{|c|}{ Storage (day) at $6 \pm 2^{\circ} \mathrm{C}$} \\
\hline & & 0 & 2 & 4 & 6 & 8 & 0 & 4 & 8 & 12 & 16 & 20 & 24 \\
\hline \multicolumn{2}{|c|}{ Control } & ND & 0 & 5 & 65 & 90 & ND & 0 & 15 & 65 & 90 & 100 & ND \\
\hline \multirow{2}{*}{$\begin{array}{c}\text { AgNPs } \\
\text { ppm }\end{array}$} & 250 & ND & 0 & 0 & 15 & 38 & ND & 0 & 0 & 0 & 15 & 35 & 64 \\
\hline & 500 & ND & 0 & 0 & 18 & 27 & ND & 0 & 0 & 0 & 10 & 20 & 25 \\
\hline
\end{tabular}

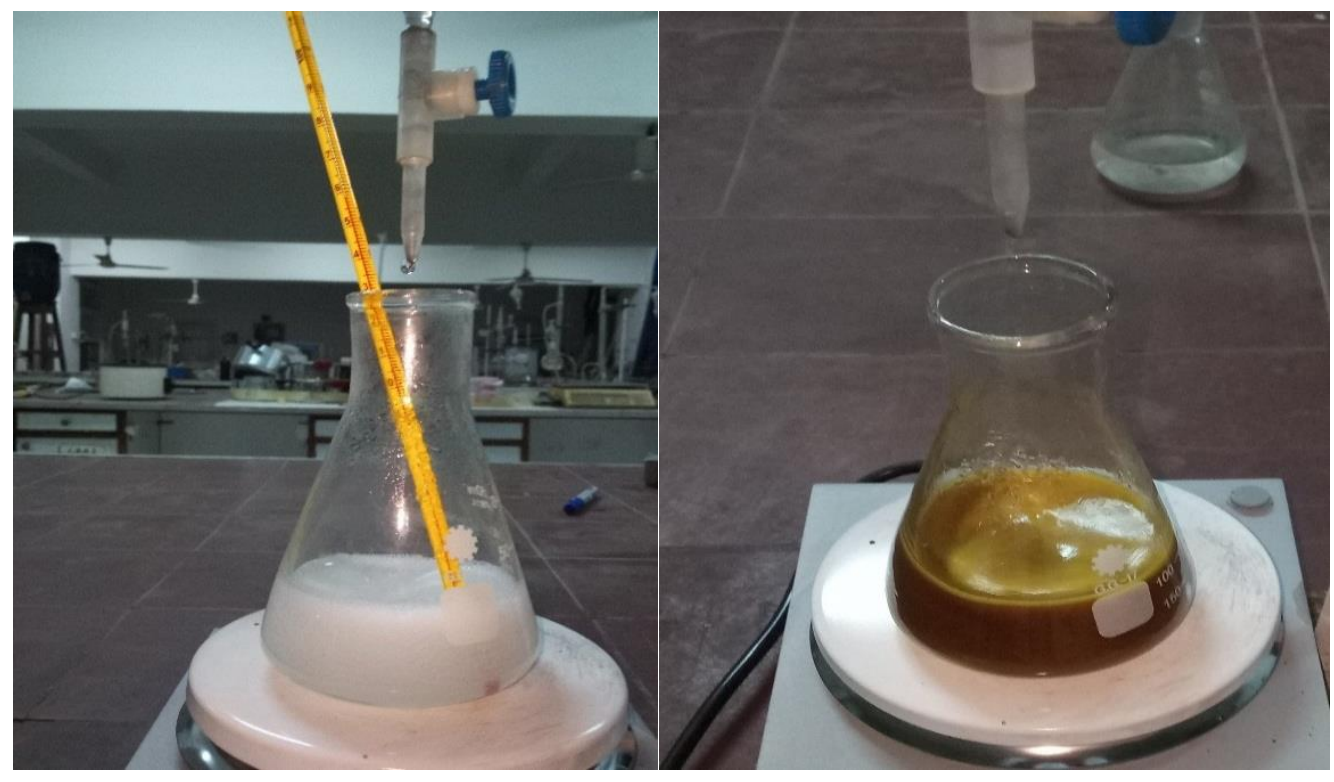

(A)

(B)

Fig. 1. (A) $\mathrm{AgNO}_{3}$ solution with starch and $\mathrm{NaOH}$ before reduction (B) Final silver dispersion formed after reduction 


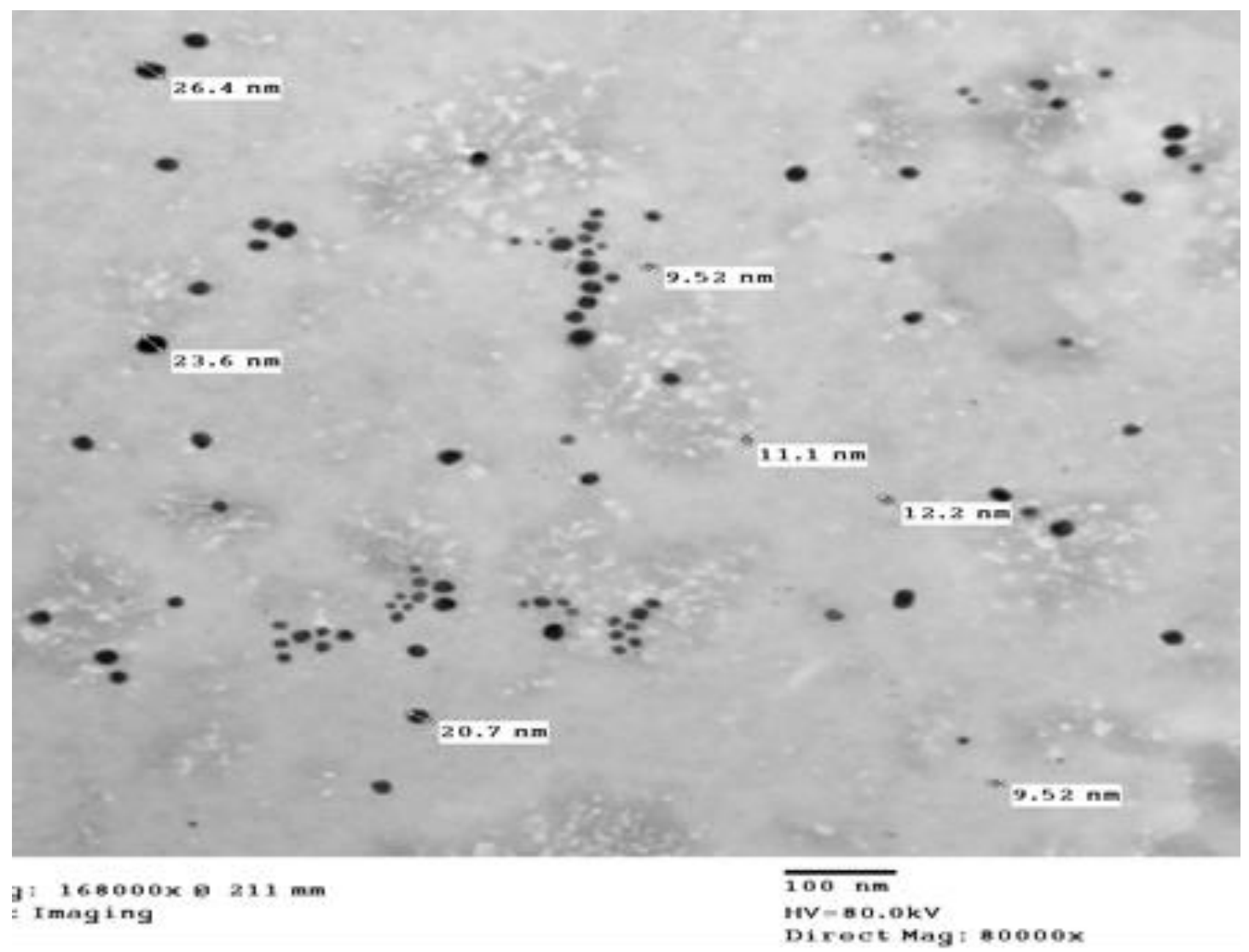

Fig. 2. Transmission electron microscopy micrograph of AgNPs

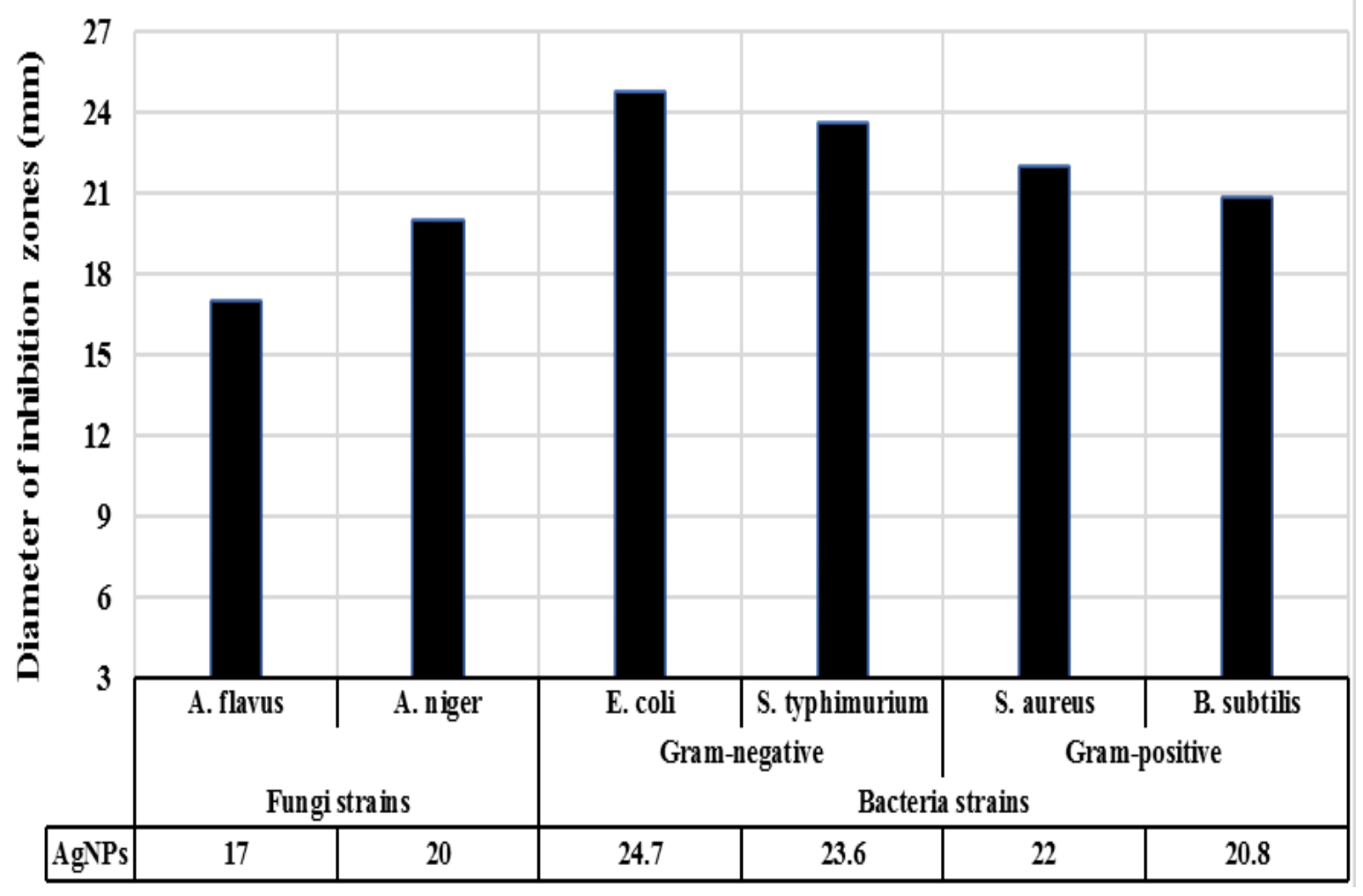

Fig. 3. Effect of AgNPs on inhibition growth of tested microorganisms 


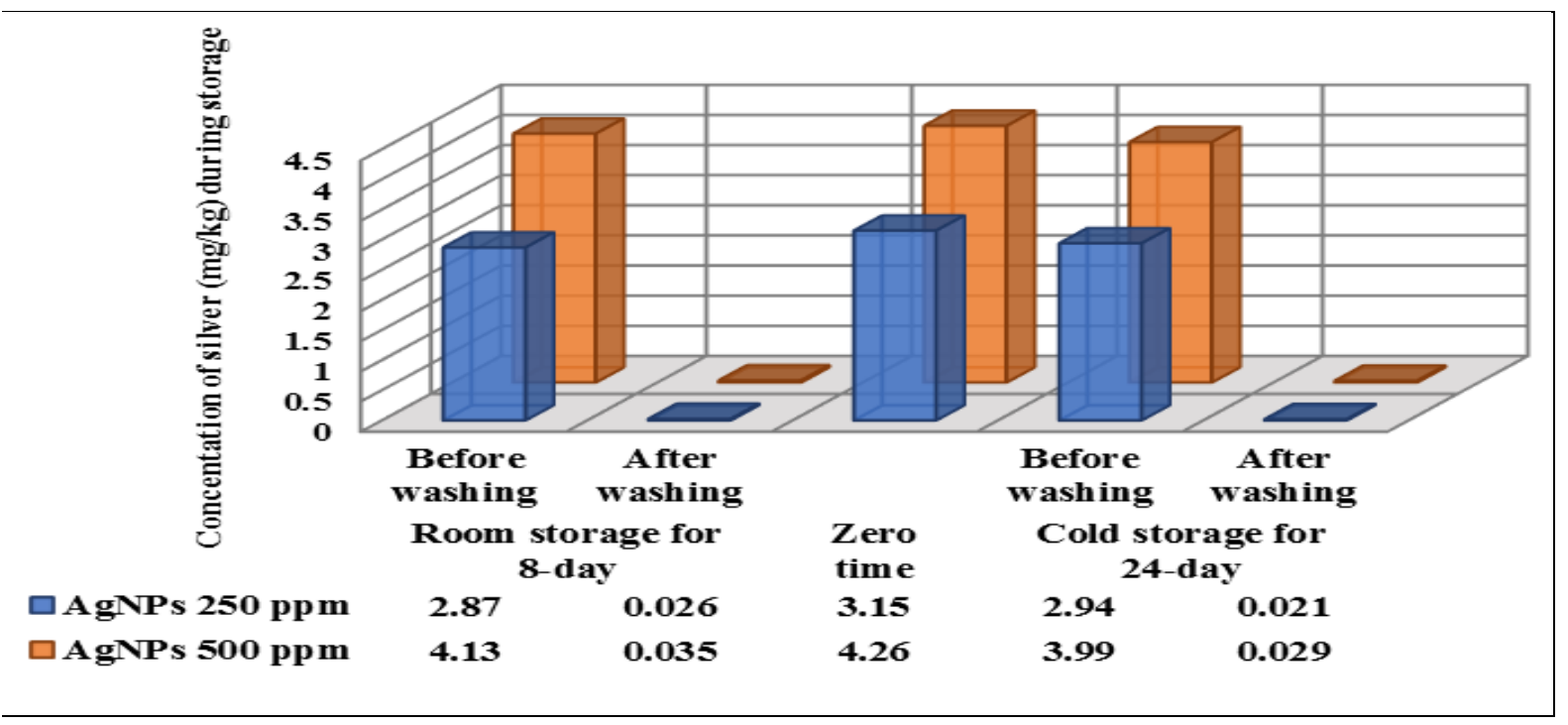

Fig. 4. Silver concentration $(\mathrm{mg} / \mathrm{kg})$ in coated apricots.

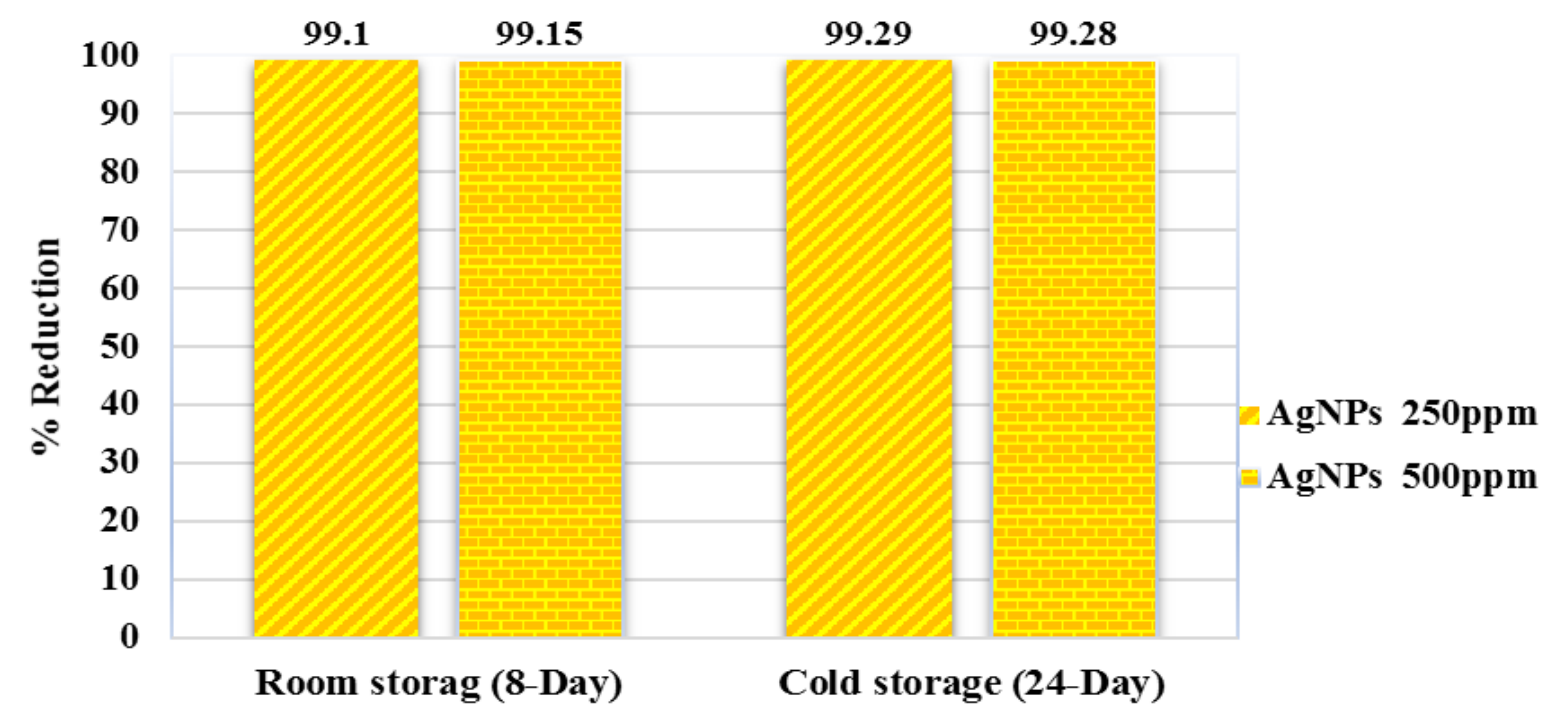

Fig. 5. Reduction (\%) of silver particles in washed apricot samples

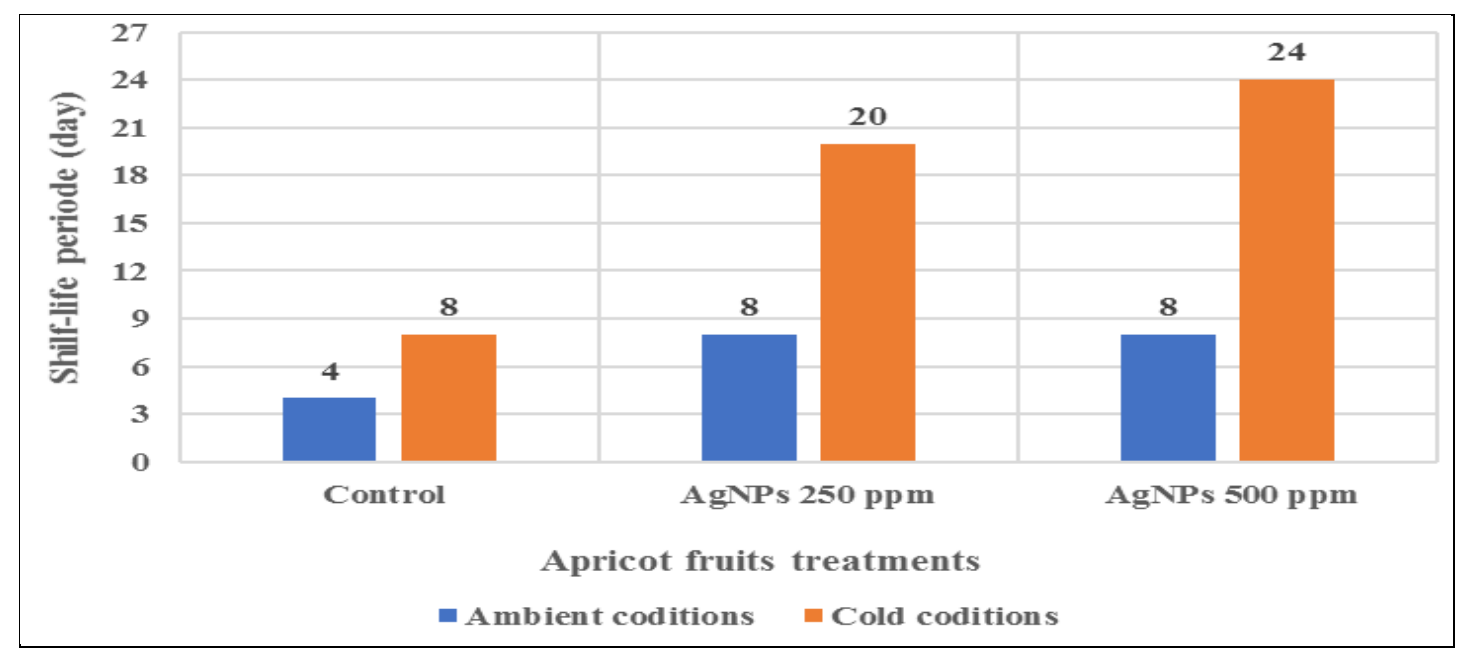

Fig. 6. Shelf-life periods of apricot samples 


\title{
تحضير وتوصيف جسيات الضضة النانوية واستخداما في تحسين جودة ثمار المشمش
}

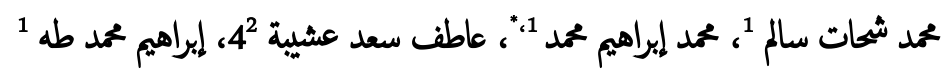

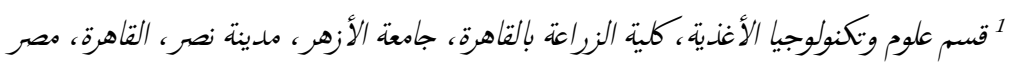

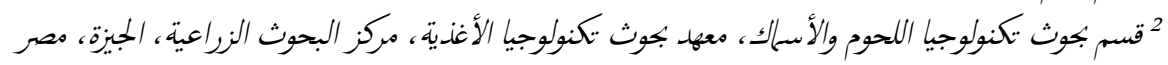

Mohammedibrahim700.el@azhar.edu.eg البريد الإيكتروني للباحث الرئيسي: *

الملخص العريي

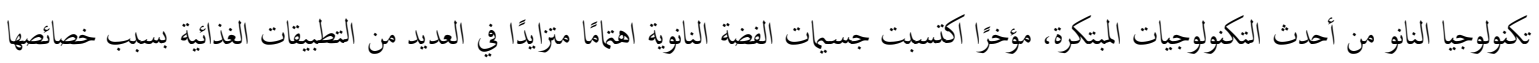

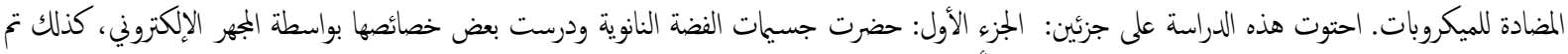

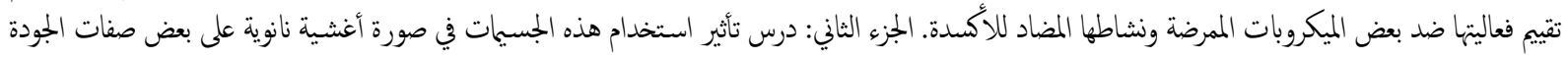

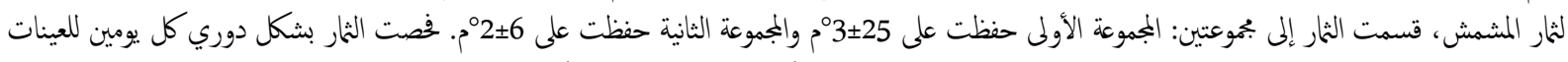

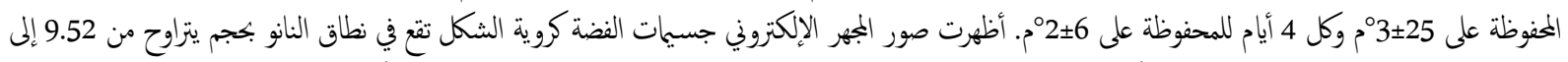

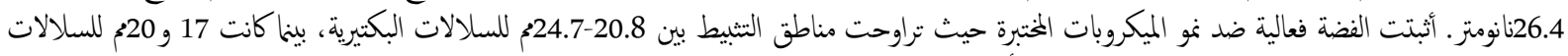

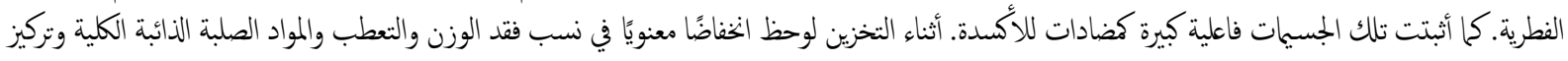

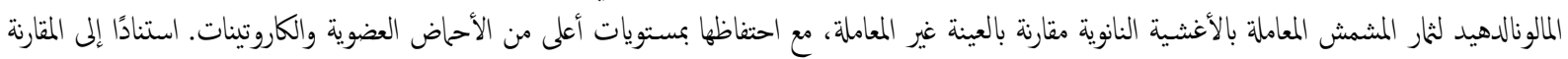

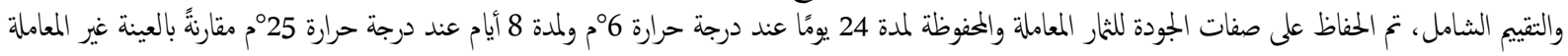

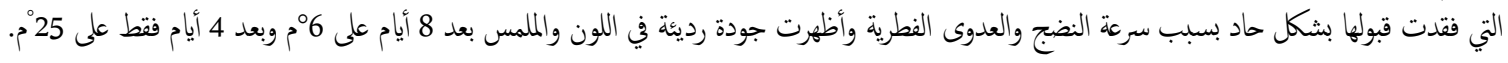

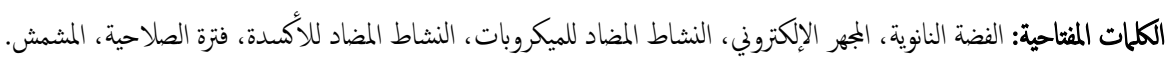

